\title{
COMPETENCE OF THE CIVIL SERVICE POLICE UNIT (CSPU) IN PROVIDING EMERGENCY FIRST AID ASSISTANCE
}

\author{
Widodo Widodo, Sumardino Sumardino, Akhmad Rifai \\ Jurusan Keperawatan Politeknik Kesehatan Surakarta, \\ Jl. Letjend Sutoyo Mojosongo Surakarta \\ widd70@yahoo.com
}

\begin{abstract}
Introduction: In the year 2014 there were 456 disasters in Indonesia, comprising 227 natural disasters, 197 non-natural disasters and 32 social disasters. The community is expected to be well prepared in accordance with their respective capacities, and this includes the Civil Service Police Unit (CSPU), which must be competent in providing emergency first aid. The aim of this study is to analyse the effect of emergency first aid training on the competence of CSPU in providing emergency first aid assistance in the Surakarta region. Methods: This study used a pre-experimental technique using a prepost test group design. The sample consisted of 107 respondents who were recruited by total sampling. Variables in this study were competencies in handling emergency first aid assistance including knowledge, attitute and practice. Data were collected by questionnaire and analysed using Wilcoxon signed-rank test with a p-value of 0.05 . Results: There were significant differences in scores on knowledge, attitudes, and practice in providing emergency first aid assistance, with a pvalue of 0.012 for knowledge, 0.000 for attitude and 0.001 for practice, respectively. Conclusions: Emergency first aid training is urgently needed for CSPU members that are ever directly in charge in the community in any situation. The CSPU must have the first aid competence to support its performance.
\end{abstract}

Keywords: Civil Service Police Unit, Competency, First Aid Emergency Training.

\section{INTRODUCTION}

Indonesia is known as an archipelago country located in the Ring of Fire area, which has the potential for a very varied array of disasters (Intarti, Fitrinita, Widyanto, \& Simarmata, 2013). In addition, the large population with various ethnic, cultural, religious and economic strata can also be risk factors for disaster. When looking at the various potentials for disaster, Indonesia becomes a country with very high level of potential hazards (potency) and various forms of natural disaster, human disaster or complex emergency (Head of BNPB Regulation No. 4 of 2008).

The Health Crisis Center of the Ministry of Health of the Republic of Indonesia noted that in the five years since 2010, Indonesia experienced 1,907 disasters (Mediastianto, 2015). Of these, 1,124 (59\%) were natural disasters, $626(33 \%)$ were nonnatural disasters and 157 (8\%) were social disasters. In 2014 there were at least 456 disasters, and these too were dominated by natural disasters 227 times (49\%), with nonnatural disasters occurring 197 times (44\%) and social disasters 32 times $(7 \%)$. The percentage of social disasters is not too big, but the number of events needs to get attention.

Various elements of society must be prepared according to the proportion of tasks and their respective functions. Research conducted by Djalali, Khankeh, Öhlén, Castrén, and Kurland (2011) in Iran stated that the victims of the earthquake were transported to a health facility without triage. Some factors that become obstacles include the lack of a well-organised team and a structured procedure. As a result, the victims cannot get the right handling according to priority and cannot get directly transported. This is one of the factors contributing to the high death rates of victims after the earthquake in Iran.

The CSPU in Indonesia is a Local Government Civil Police whose main duty is to enforce local regulation and maintain public order and peace in society by implementing decentralization. The CSPU is expected to be able to conduct first aid correctly to victims of any types of disasters including clashes. In reality, there is no evidence that first aid training has been provided to them. Thus, the CSPU members need to be equipped with basic emergency or first aid training so that their role can be empowered. The other critical aspects according to the appendix are prioritizing actions and deciding on action strategies. These skills highly contribute to effective emergency care treatment. It is therefore clear that much attention needs to be paid to first aid training to empower each CSPU to become highly competent. Further injuries and even fatalities as a result of improper handling can then be avoided. The existing phenomenon indicates that the CSPU 
has not been equipped with first aid competence that complies with the field of preparedness and prevention of emergency and disaster. As a consequence it is very risky when members of the CSPU must provide first aid. By looking at this phenomenon, the aim of this study is to analyse the effect of first aid emergency training on the competence of CSPU in providing first aid assistance in the Surakarta region.

\section{MATERIALS AND METHODS}

This study used a pre-experimental approach with a pre-post test group design. The population in this study consisted solely of members of the CSPU who were active in the city of Surakarta. The sample comprised 107 respondents who were recruited by total sampling. The independent variable was emergency first aid training, and the dependent variable was competence in providing emergency first aid assistance include knowledge, attitude, and practice. Data were collected via a questionnaire that was developed based on recommendations by the Center for Crisis Response at the Ministry of Health of Indonesia and was presented to three experts, consisting of emergency nursing practitioners and academics, who conducted a validity test. Small revisions and edits were made after being corrected by the experts until the questionnaire met the valid criteria. All respondents were trained in emergency first aid that consisted of CPR, bandaging and splinting, stabilization and evacuation. In addition, there were interviews with some respondents in order to get deeper information. The data conducted were analysed using Wilcoxon signed-rank test with a p-value of 0.05 , and the results of the interview were displayed descriptively. Ethical clearance to conduct this study was granted by the ethical commitee of the School of Nursing at the Health Polytechnic of Surakarta.

\section{RESULTS}

As shown in Table 1, there were 107 respondents in total, most of whom had moderate knowledge $(72 \%)$ before training. After training, there was an increase from $15.9 \%$ to $30.8 \%$ in respondents in the high knowledge category. From the statistical analysis gained using Wilcoxon signed-rank test, it can be seen that the p-value is 0.012 $(<0.05)$. This indicates that there is a significant difference in respondent knowledge before and after the training.

From Table 2 it can be seen that before the training there were no respondents in the high attitude category, but following the

Table 1. Differences in knowledge of respondents pre- and post-intervention

\begin{tabular}{|c|c|c|c|c|c|}
\hline \multirow{2}{*}{ No. } & \multirow{2}{*}{ Knowledge } & \multicolumn{2}{|c|}{ Before } & \multicolumn{2}{|c|}{ After } \\
\hline & & $\mathrm{N}$ & $\%$ & $\mathrm{~N}$ & $\%$ \\
\hline 1 & High & 17 & 15.9 & 33 & 30.84 \\
\hline 2 & Moderate & 77 & 72.0 & 64 & 59.81 \\
\hline 3 & Low & 13 & 12.1 & 10 & 9.35 \\
\hline & Total & 107 & 100.0 & 107 & 100.0 \\
\hline
\end{tabular}

Table 2. Differences in attitute of respondents pre- and post-intervention

\begin{tabular}{|c|c|c|c|c|c|}
\hline \multirow{2}{*}{ No. } & \multirow{2}{*}{ Attitude } & \multicolumn{2}{|c|}{ Before } & \multicolumn{2}{|c|}{ After } \\
\hline & & $\mathrm{N}$ & $\%$ & $\mathrm{~N}$ & $\%$ \\
\hline 1 & High & 0 & 0 & 8 & 7.48 \\
\hline 2 & Moderate & 26 & 24.3 & 41 & 38.32 \\
\hline 3 & Low & 81 & 75.7 & 58 & 54.21 \\
\hline & Total & 107 & 100.0 & 107 & 100.0 \\
\hline
\end{tabular}

Table 3. Differences in practice of respondents pre- and post-intervention

\begin{tabular}{|c|c|c|c|c|c|}
\hline \multirow{2}{*}{ No. } & \multirow{2}{*}{ Practice } & \multicolumn{2}{|c|}{ Before } & \multicolumn{2}{|c|}{ After } \\
\hline & & $\mathrm{N}$ & $\%$ & $\mathrm{~N}$ & $\%$ \\
\hline 1 & High & 1 & 0.93 & 2 & 1.87 \\
\hline 2 & Moderate & 16 & 14.95 & 38 & 35.51 \\
\hline 3 & Low & 90 & 84.11 & 67 & 62.62 \\
\hline & Total & 107 & 100.0 & 107 & 100.0 \\
\hline
\end{tabular}


training $7.48 \%$ of respondents had a high level in attitude. The upward trend also occurred in the moderate level of attitudes with a rise from $24 \%$ of respondents to $38.3 \%$. In contrast, the $75.7 \%$ of respondents who initially had a low attitude category changed to $54 \%$ of respondents. From the statistical analysis using Wilcoxon signed-rank test, it can be seen that the $\mathrm{p}$-value value is $0.000(<0.05)$, which therefore indicates that there is a significant difference in the respondents' attitude before and after the training.

As shown in Table 3, the $84.11 \%$ of respondents in the low category reduced to $62.62 \%$ respondents following training. In the moderate level, there was an increased number of respondents after training from $14.95 \%$ to $35.51 \%$. From the statistical analysis using Wilcoxon signed-rank test, it can be seen that the p-value is $0.001 \quad(<0.05)$, which therefore indicates that there is a significant difference in respondents' practice before and after the training.

\section{DISCUSSION}

Schipper and Pelling (2006) describe the four stages of disaster management required to improve the effectiveness of emergency response as follows: continuum of prevention and mitigation, preparation and planning, decrease response and relief, and recovery. These components need to achieve the same concentration and seriousness because each stage can affect the end result. The final goal is to reduce the impact of disasters on human health and safety by delivering urgent health interventions and provision of care during and after the disaster (Sauer, McCarthy, Knebel, \& Brewster). Comparative study, education and training, and simulation can be carried out when preparing and planning emergency management. Successful training will greatly impact the change in understanding of tasks and better roles, which can reduce the psychological pressure, especially during and after the operation, and even assist the mastery of future disaster management (Pederson, Gjerland, Rund, Ekeberg, \& Skogstad, 2016).

Djalali, Khankeh, Ohkel, Castren, and Kurland (2011) revealed one of their findings in Iran of the involvement of military forces, especially their participation in air evacuation of victims and the provision of troops as an important source of energy. The same experience was also found in Indonesia regarding military troop preparedness before the disaster. One of the components that exist in Indonesia besides the military forces and other sources that have the potential to be prepared is the CSPU.

The main task of the police in the Republic of Lithuania is to serve the community and to ensure the safe living of citizens. It strives to be an active guarantor of public safety and not just criminal registry (Janusauskas, 2013). Safe living has a broad meaning that includes saving people from any dangerous situations. As noted in the Standard Competency Description of the CSPU (Letter of the Minister of Home Affairs, Number: 800/120/SJ year 2016) there are several units of skills or competencies and knowledge and attitudes that need to be mastered by CSPU members in order to perform their duties. One of the requirements related to the field of disaster preparedness that must be mastered by each member of the CSPU is first aid competence. According to Kundra and Cherian (2015) and Sonmez (2017), the ability to receive information and responses to knowledge integration, decision making, communication and teamwork can be assessed through simulations designed as similarly as possible to actual events. Various training is required by members of the CSPU to equip their abilities related to the various competence units that become their responsibilities. Increased knowledge through training, such as basic emergency care for special lay people or first aid in accidents, is necessary considering the tasks of the CSPU that directly relate to the community under any circumstances. Basic emergency rescue training has been shown to significantly increase the knowledge of CSPU personnel. Knowledge forms the basis for the anticipation, decision-making and handling steps of sharing actions appropriately. Mistakes in making decisions about an action can be fatal.

In-depth interviews with some respondents stated their understanding of the things that should and should not be done first time when providing first aid. Respondent 1 stated: "Until now I did not know about first aid, so if there was a sick person on the road I would just transfer them to the hospital as soon as possible." Respondent 7 stated: 
"Previously, we did not know which one needed to be helped first and did not know how to provide help". This is in accordance with a previous study conducted by Yasin, Malik, Nasreen, and Safdar (2009) where there were limited professional health personnel in disaster areas and most earthquake victims were transported from the disaster site without any initial rescue action. In fact, early rescue action is essential to restore vital bodily functions and avoid worse conditions during the transfer of the victim. Therefore, through effective emergency first aid training, the number of deaths due to lack of help before the transport of the victim will be reduced.

Increased knowledge is also proved by respondents at the time of evaluation either individually or through scenario or simulation. Respondents follow every step of the procedure when demonstrating every skill and even when performing the simulation. Kundra and Cherian (2015) added that procedural actions that follow standardized protocols can reduce morbidity and mortality rates. In this basic emergency treatment training, procedures are standardized by several institutions or organizations such as CPR as recommended by the American Heart Association (2015). During the evaluation and simulation of basic handling of the victims in emergency situations, coordination and cooperation emerged. Respondent 11 mentioned: "We just found out there are steps on how to perform first aid during a disaster, starting with hazard identification, choosing which one should be helped and how to help together with the team." A similar opinion was expressed by respondent 17: "Until now we did not think that working with friends and coordination is very important. Lack of coordination may not really give effective results and may even endanger the rescuer".

Kundra and Cherian (2015) explain that the attitude domain needs to be examined to make sure whether trainees have been able to internalize the values of knowledge of attitudes and beliefs to influence professional behavior. To assess the ability of this integration, simulation method can be used. A member of the CSPU is required to have a firm attitude, be brave, disciplined, proactive, responsive, meticulous and agile. During an the emergency situation the individual must possess these attitudes and abilities. The ability to anticipate becomes the initial capacity of preparedness of the officer in providing help. Good preparation can strengthen the team's capacity, while performing complex tasks and daily training and hands-on practices provides opportunities to develop skills and adds more confidence to the roles provided (Pederson, 2016).

\section{CONCLUSIONS}

First aid emergency training is urgently needed for the CSPU that are directly in charge in the community under any circumstances. The CSPU must have first aid competence to support its performance. Stakeholders are expected to take policy measures on the strengthening of the CSPU's competence in relation to one of the requirements for the ability to master the competence of first aid as mandated by ministerial regulation. In addition, stakeholders are expected to conduct periodic evaluations of the CSPU personnel preparedness in anticipation, disaster, and post-disaster. The CSPU members are expected to conduct regular disaster preparedness exercises, so that they will be well prepared in case of disaster to reduce the impact of the disaster.

\section{REFERENCES}

American Heart Association. (2015). Highlights of the 2015 American Heart Association Guidelines Update for CPR and ECC.

Arikunto, S. (2010). Prosedur Penelitian Suatu Pendekatan Praktek. Edisi Revisi VI. Jakarta : Rineka Cipta.

Djalali, A., Khankeh, H., Öhlén, G., Castrén, M., \& Kurland, L. (2011). Facilitators and obstacles in pre-hospital medical response to earthquakes: a qualitative study. Scandinavian Journal of Trauma Resuscue Emergency Medicine. 2011; 19: 30. Doi: 10.1186/1757-7241

Intarti, Y.R., Fitrinita, I.S., Widyanto, M.R., \& Simarmata, H.A. (2013). Towards Disaster Management in Indonesia Case Studies Jakarta and Yogyakarta Provinces, International Journal of Disaster Recovery and Business Continuity Vol.4 (2013), pp.11-22. Retrieved November 20, 2017 from: 
http://www.sersc.org/

journals/IJDRBC/vol4/2.pdf.

Janusauskas, A. (2013). How to Develop a Professional Police Officer?Journal of Education and Human Development, Vol. 2 No. 2.

Kundra, P. \& Cherian, A. (2015). Simulation for "Evaluation" and teaching "Standard operating procedures". Journal of Anaesthesiology Clinical Pharmacology. 31(2): 270-271. Doi: 10.4103/0970-9185.155208

Lampiran-Surat Edaran Menteri Dalam Negeri. Nomor : 800/120/SJ Tanggal : 15 Januari 2016 Tentang : Standar Kompetensi Jabatan Fungsional Polisi Pamong Praja. Uraian Standar Kompetensi Jabatan fungsional polisi pamong praja Retrieved September 18, 2017 from

http://bpsdm.kemendagri.go.id/web9/s ites/default/files/inline-

files/standar_kompetensi_polpp_final. pdf Malik, A.Y., Malik, S.A., Nasreen, G. \& Safdar, C.A. (2009). Experience with mass casualties in a subcontinent earthquake. Turkish Journal of Trauma and Emergency Surgery. Ulus Travma Acil Cerrahi Derg. 15(5):487-92. Retrieved from September 2, 2017, from http://tjtes.org/eng/jvi.aspx?un=UTD36539.

Mediastianto, E. (2015). Statistik Kejadian Bencana tahun 2015. Pusat Krisis Kesehatan Kementerian Kesehatan Republik Indonesia. Retrieved September 18, 2017 from : http://penanggulangankrisis.kemkes.g o.id/statistik-kejadian-bencana-tahun2014 .

Pederson, M.J.B., Gjerland, A., Rund, B.R., Ekeberg, O., \& Skogstad, L. (2016). Emergency Preparedness and Role Clarity among Rescue Workers during the Terror Attacks in Norway July 22, 2011. Retrieved September 3, 2017 from:

http://journals.plos.org/plosone/article ?id=10.1371/journal.pone. 0156536

Peraturan Kepala BNPB Nomer 4 Tahun 2008 Tentang Pedoman Penyusunan Rencana penanggulangan Bencana. Retrieved September 18, 2017 from http://www.gitews.org/tsunami-

kit/en/E6/further_resources/national_1 evel/peraturan kepala BNPB/Perka\% 20BNPB\%204-

2008_Pedoman\%20Penyusunan\%20R encana\%20Penanggulangan $\% 20 \mathrm{Benca}$ na .pdf

Peraturan Menteri Kesehatan Nomor 19 tahun 2016 tentang SPGDT

Peraturan Pemerintah Republik Indonesia Nomor 32 tahun 2004 Tentang Pedoman Satuan Polisi Pamong Praja. Retrieved March 2, 2017 from: https://portal.mahkamahkonstitusi.go.i d/ eLaw/mg58ufsc89hrsg/pp32_2004.pdf

Pusat Data Informasi dan Humas - BNPB, Retrieved March 2, from : http://dibi.bnpb.go.id/data-bencana diunduh pada 2 Maret 2017

Pusat Penanganan Krisis Kesehatan, (2010). Pedoman Gladi Kesiagaan Bencana. Jakarta: PPK Kesehatan Kemenkes RI.

Schipper, L., \& Pelling, M. (2006). Disaster risk, climate change and international development: scope for, and challenges to, integration. Disasters. 30:19-38. Doi: 10.1111/j.14679523.2006.00304.x

Sonmez, P. (2017). Association of Cognitive, Affective, Psychomotor and Intuitive Domains in Education, Sönmez Model. Universal Journal of Educational Research 5(3): 347-356. Doi : 10.13189/ujer.2017.050307

Sauer, L.M., McCarthy, M.L., Knebel, A. \& Brewster, P. (2009). Major influences on hospital emergency management and disaster preparedness. Disaster Med Public Health Prep. 3:S68. Doi: 10.1097/DMP.0b013e31819ef060

Undang-Undang Republik Indonesia Nomor 24 Tahun 2007 tentang Penanggulangan Bencana.

Undang-undang Republik Indonesia Nomor 32 tahun 2004 Tentang Pemerintahan daerah.

Wang, J., Ma, L., \& Lu, Y.Q. (2015). Strategy analysis of cardiopulmonary resuscitation training in the community. Journal of Thoracic Disease. 7(7): E160-E165. Doi: 10.3978/j.issn.2072-1439.2015.06.09. 